\title{
THE VARIOUS FACTORS OF SUPPORTING AND INHIBITING THE IMPLEMENTATION OF CHARACTER EDUCATION (Study at Madrasah Aliyah Negeri 1 Mamuju)
}

\author{
Wahyun ${ }^{1}$ \\ Bahaking Rama ${ }^{2}$ \\ Susdiyanto ${ }^{3}$ \\ Andi Achruh ${ }^{4}$ \\ Postgraduate Program of UIN Alauddin Makassar ${ }^{1,2,3,4}$
}

\begin{abstract}
This article examines the various factors supporting and inhibiting the implementation of character education in Madrasah Aliyah Negeri 1 Mamuju. The background of this research is the importance of character education to shape students' character as a solution to moral damage and the threat of national disintegration. This research is descriptive qualitative, with a phenomenological approach. The data sources of this research are primary and secondary data. Primary data was taken from the stakeholders of MAN 1 Mamuju through interviews. Meanwhile, secondary data were taken from documents and literature related to this research. The main instrument is the researcher himself as the key instrument, while the interview guide, observation and documents are complementary instruments. The analysis used is data reduction, data presentation and conclusion drawing. The results obtained in this research are strategic supporting factors, namely planning, control and evaluation, and operational ones, namely the availability of professional educator resources. In contrast, the inhibiting factors are student discipline and limited facilities owned.
\end{abstract}

Keywords: Implementation; Supporting and Inhibiting; Character Education

\section{INTRODUCTION}

The government has issued Presidential Regulation (Perpres) No. 87 of 2017 concerning strengthening character education. The Presidential Decree states that the education movement is under the education unit's responsibility to strengthen students' character through harmonization of heart, taste, thought, and exercise by involving education units, families, and communities. ${ }^{1}$ This presidential regulation also annuls various previous regulations in case of conflict. It is interesting to look at the Presidential Regulation because it regulates integrating intra-curricular, co-curricular and extra-curricular activities at once.

The nation's founders had discussed the urgency of character education in Indonesia for a long time, especially when this country was experiencing a human resource crisis. The discourse is based on the fact that various morality cases occur on a macro scale, such as corruption, collusion, nepotism that involve many corrupt state institutions, and on a micro-scale, such as moral decadence and drug abuse free sex, abortion,

${ }^{1}$ President of the Republic of Indonesia, The Strengthening Character Education, Presidential Regulation of the Republic of Indonesia No. 87 of 2017, September 6, 2017 
(Study at Madrasah Aliyah Negeri 1 Mamuju) and others. All forms of crime are caused by the character crisis experienced by the Indonesian people. The relationship between the crisis of character and human resources has been warned in the QS Ar-rum/30:41.

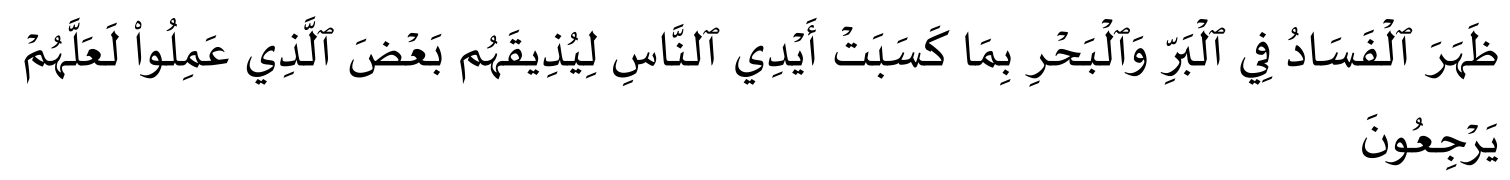

The Translation:

"Evil (sins and disobedience of Allah) has appeared on land and sea because of what the hands of men have earned (by oppression and evil deeds), that He (Allah) may make them taste a part of that which they have done, in order that they may return (by repenting to Allah, and begging His Pardon). "2

According to Shihab, the interpretation of Al-Misbah states that this verse implies no creation of Allah is damaged, polluted or out of balance as in its original creation. However, the arrival of damage is the result of human actions that deliberately try to change the nature of Allah, which has been created in a perfect and balanced manner. ${ }^{3}$

Erie Sudewo, in his book Best Practice Character Building, said that Indonesia's increasingly chaotic crisis is believed to be due to a lack of character. ${ }^{4}$ Generally, Education at the primary and secondary levels still develops hard skills (cognitive domains) while the soft skills domains have not been implemented optimally. Suparno once expressed this opinion in Harian Kompas said:

"Our Education still dominantly emphasizes the cognitive aspect. This is also still limited to looking for numbers, not the students' critical analysis skills of events encountered in everyday life." 5

It was also stated by Rukiyati et al. in their article journal that the phenomenon of moral degradation and increasing violence occurred indicates that Education has not been entirely successful in building students' character to become good people. One of the reasons is that the values education is not yet comprehensive but is more cognitive in nature. ${ }^{6}$

From the various character problems mentioned earlier, it can be concluded that the goals of national Education in general and Islamic Education in particular, have not been achieved. The purpose of national Education as stated in the Law of the Republic of Indonesia No. 20 of 2003 Article 3 concerning the National Education System states that:

"National Education has the function of developing capabilities and shaping the character and civilization of a dignified nation in the context of educating the

\footnotetext{
${ }^{2}$ Ministry of Religion, Al-Qur'an and its Translation, p. 647.

${ }^{3}$ Quraish Shihab, Tafsir Al-Misbah, Pesan, Kesan, dan Keserasian Al-Qur'an vol.10 (Jakarta: Lantera Hati, 2011), p. 235

${ }^{4}$ Anas Salahudin and IrwantoAlkrienciehie, Pendidikan Karakter Pendidikan Berbasis Agama dan Budaya Bangsa, (Bandung: Pustaka Setia, 2013), p. 31.

${ }^{5}$ Suparno, P, Harapan Untuk Kurikulum Baru, (Kompas, 29 September 2012)

${ }^{6}$ Rukiyati, dkk., in Jurnal of Penanaman Nilai Karakter Tanggung Jawab Dan Kerja Sama Terintegrasi Dalam Perkuliahan Ilmu Pendidikan.
} 
nation's life. National Education aims to develop the potential of students to become human beings who believe and fear God Almighty, have a noble character, healthy, knowledgeable, capable, creative, independent, and become democratic and responsible citizens."7

The law explicitly describes the three goals of Education. The first is forming religious characteristics so that humans have spiritual piety. Furthermore, forming humans who have social and contributive characteristics to life, therefore, they can have social piety. The third is to form intellectual characteristics to make humans have good personal qualities.

The goals of national Education are also in line with the goals of Islamic Education. In general, Islamic Education aims to form humans as perfect servants of Allah, namely devoting their lives to Allah SWT. Therefore, all activities of a Muslim must have the value of worship. In another verse, it is also explained that the role of humans on earth is as caliph or leader. ${ }^{8}$

A leader should possess Characters to include capacity, dedication and loyalty, integrity, synergy, and professionalism. In more detail, the goals of Islamic Education that Islamic education experts have defined include the pattern of a rounded human personality through psychological exercises, brain intelligence, reasoning, feelings and senses. This Education must serve human growth, and all aspects include spiritual, intellectual, imagination, physical and language. ${ }^{9}$

The similarity of characteristics mentioned in national Education and Islamic Education is the formation of human character. Education aims to instil character values in students in every learning process. Integrating character values in all learning materials is the right idea in internalizing these character values. Intellectual intelligence that is not balanced with character will not produce a contributive outcome.

There is exciting research on the correlation between the affective domain (soft skill) and success. According to research at Harvard University in the United States, it turns out that a person's success is not only determined solely by knowledge and technical abilities (hard skills) but is also determined by the ability to manage oneself and others (soft skills). This research reveals that success is only determined by 20 per cent by hard skills and 80 per cent by soft skills. The most successful person in the world can succeed because soft skills rather than hard skills support them. It implies that the quality of student character education is crucial to be improved. ${ }^{10}$

Madrasah Aliyah Negeri 1 (MAN) Mamuju is one of the Madrasah that provides Education which has a slogan/mission, Madrasas that are excellent in Science and Technology (IPTEK), Faith and Taqwa (IMTAQ), exemplary behaviour and environmental culture. In the process, this madrasa internalizes character values in its various activities. Among the initial descriptions obtained from the object under study

\footnotetext{
${ }^{7}$ Departemen Agama RI Direktorat Jenderal Pendidikan Islam, Undang-Undang Republik Indonesia Nomor 20 Tahun 2003 tentang Sisdiknas(Jakarta: Depag Press, 2007), p. 5.

${ }^{8}$ Departemen Agama Republik Indonesia, Al-Qur'an dan Terjemahan ( Cetakan 10, Bandung, 2014) p. 13

${ }^{9}$ H.M. Arifin, Pendidikan Islam Suatu Tinjauan Teoritis danPraktis Berdasarkan Pendekatan Interdisipliner, (Jakarta: Bumi Aksara,), p. 41.

${ }^{10}$ See Akhmad Sudrajat, about Chacter Education, (Posted on 20 Agustus 2010), http:www.pendidikan karakter.ac.id
} 
(Study at Madrasah Aliyah Negeri 1 Mamuju) are nine cultural development/habituation programs at MAN 1 Mamuju, namely, the learning process, midday prayers in congregation, 5S (salam, senyum, sapa, sopan and), ceremonies, duha prayers, Arabic, English, literacy culture and clean culture.

The decline in mortality among students and the young generation, which is increasingly being concerned, has encouraged schools or Madrasah to increase the efforts to improve their students' character education. Based on the observation results at Madrasah Aliyah Negeri 1 Mamuju, there is a perception from some parents of students who send their children to Madrasah that Madrasah is a place to develop attitudes toward their children. It is driven by the behaviour of juvenile delinquency done by the previous children. This condition is possible for some students in Madrasah Aliyah Negeri 1 Mamuju who violate the rules. However, the author has not found information that students commit serious violations. Therefore the authors consider it necessary to conduct more in-depth research on the cultural development/habituation program in Madrasah Aliyah Negeri 1 Mamuju.

From those conditions, the researchers examined the reality in Madrasah Aliayah Negeri 1 Mamuju by looking at the existing problems associated with the curriculum made by the Madrasah. In addition, researchers were also interested in exploring more deeply the implementation of character education in MAN 1 Mamuju and the results of existing character education and the factors that influence it.

\section{THEORETICAL REVIEW}

\section{A. The Implementation Forms of Character Education}

1. Character Education in Learning Activities

According to Yahya Khan, there are four types of character education that have been known and implemented in the educational process, as follows:

a) Character education is based on religious values, the truth of God's revelation (moral conservation). In this case, several things are contained in religious values, such as:

1) Teaching to always think

2) Strengthening self-worth based on God's rules contained in the holy book

3) Mastering feelings, both towards oneself and towards others

4) Being open to a caring relationship with each other

5) Developing potential to serve and lead.

b) Character education is based on cultural values such as among others in the form of character, Pancasila, literary appreciation, exemplary historical figures and national leaders (environmental conservation)

c) Environmental-based character education (environmental conservation)

d) Character education is based on self-potential, namely personal attitudes resulting from the awareness process of self-potential empowerment, which is directed at improving the quality of Education (humanist conservation) ${ }^{11}$

\section{0), p. 2.}

${ }^{11}$ Yahya Khan, Pendidikan Karakter Berbasis Potensi Diri, (Yogyakarta: PustakaPublishing, 
Character education is not limited to the transfer of knowledge about good values but reaches how to make these values embedded and integrated into the totality of thought-action. ${ }^{12}$

Lickona in Education for Character: How Our School Can Teach Respect and Responsibilty states that character building includes the following three things: knowing the good, desiring the good and doing the good. ${ }^{13}$

Muhajir offers an alternative to moral values through the internalization process. Moral values are actualized in students. On the other hand, students understand how important emotional and spiritual intelligence are by internalizing or living up to these moral values. Because the concept of faith can go up and down or thin out, it is a must to internalize it rationally and through total comprehension. ${ }^{14}$

2. Character Education in Self-Development Programs and School Culture

Johanson et al. state that schools have become an institution to prepare students for life for a long time, either in academics or as a moral agent in society. In the explanation, it was emphasized that schools do not only focus on developing academic abilities but also need to pay attention to the moral development of students. Therefore, later, they can be ready to be accepted by the social environment in which they live and become moral agents in society. ${ }^{15}$ Asmani said character education carried out in schools is what teachers do to influence students' character. ${ }^{16}$ In character education, the teacher has a very vital role. Nucci \& Narvaez said that from a philosophical perspective, moral and character educators have a significant role in the moral development of students through a "hidden curriculum", which is manifested in the interpersonal environment of schools and classrooms. The character education curriculum does not have to be explicitly written but can be internalized through activities in the classroom. Students will develop their conception of good behaviour by observing the behaviour of teachers in the classroom and through the habits they make in class. ${ }^{17}$

Kessler said the same thing that students would observe the teacher's behaviour in the classroom, which includes how the teacher manages to learn, manages the class, copes with pressure, develops positive relationships with others, shows a stable temperament, and reacts well to problems that arise. In this case, the classroom atmosphere is created to use as an experimental laboratory.

Zuchdi's findings at all levels of Education in the Special Region of Yogyakarta shows as follows:

\footnotetext{
${ }^{12}$ Dimenson, Sara, Ed, Character is Key: How to Unlock the Best in Our Children and in Our Self, (Ontario: John Wiley and Sons Canada, 2009)

${ }^{13}$ Lickona, Thomas, Education for Character: How Our School Can Teach Respect and Responsibility, (New York: Bantam Books, 1991)

${ }^{14}$ Muhadjir, Noeng, Ilmu Pendidikan dan Perubahan Sosial, (Yogyakarta: Rake Sarasin, 2003), p. 164.

${ }^{15}$ Johansson, E, dkk, "Practices for Teaching Moral Values in the EarlyYears: A Call for A Pedagogy of Participation". Education, Citizenship and Social Justice, h. 109.

${ }^{16}$ Asmani, Jamal Ma'mur, Pendidikan Karakter di Sekolah ,(Yogyakarta: DIVA Press, 2011) p.31

${ }^{17}$ Nucci, L. P., \& Narvaez D, HandbookOf Moral and Character Education, (New York: Routledge, 2008) p. 175.
} 
(Study at Madrasah Aliyah Negeri 1 Mamuju)

a. The institutional context of the school is still not optimally supporting the implementation of character education;

b. The indoctrination strategy is still used even though the portion is not too large, the level of exemplary still needs to be added, the facilitation of very appropriate values for training decision-making abilities is not widely used, the development of life skills (soft skills) related to values and morality is also not maximal;

c. The climate of character education is not yet entirely conducive. Several suggestions were put forward as follows:

1) Every educational institution starting from Kindergarten to Senior High School, even higher education institutions should have an integrated character education program with all fields of study through both intra-curricular and extra-curricular activities;

2) The school's institutional context and learning climate must be conducive to character building.

Model of character education in Gontor Islamic boarding school. According to Zarkasyi, Gontor Islamic Boarding School has implemented character education through:

a. Giving an example (uswah hasanah) in terms of the values of sincerity, struggle, sacrifice, sincerity, simplicity, and responsibility;

b. Conditioning life in a dormitory environment therefore that the learning process takes place continuously under the control of the teacher;

c. Provide guidance on values and philosophy of life;

d. Assigning them to be able to live independently by taking care of themselves, managing businesses, leading organizations and the community;

e. Get used to living disciplined, obedient to worship and obeying the lodge rules. ${ }^{18}$

Meanwhile, the Ministry of National Education defines character as "a person's character, character, morals, or personality formed from the internalization of various virtues that are believed and used as a basis for perspective, think, behave, and act". In addition, the Ministry of National Education also revealed that providing cultural and national character education to students means that they have developed Pancasila values through heart, brain, and physical Education.

To implement character education effectively, Lickona, Schaps, and Lewis outline eleven principles of effective character education, namely:

a. Character education promotes core ethical values as the basis of good character;

b. "Character" must be comprehensively defined to include thinking, feeling, and behavior;

\footnotetext{
${ }^{18}$ Zarkasyi, Abdullah Syukri, Pola Pendidikan Pesantren Dalam Pembentukan Karakter Bangsa. Paper was presented in the Seminar: Pendidikan Karakter Bangsa melalui Pola Pendidikan Pesantren. Balitbang, Kemendiknas, 10-12 December 2010, at Hotel Salak, Bogor.
} 
c. Effective character education requires an intentional, proactive, and comprehensive approach that promotes the core values in all phases of school life;

d. The school must be a caring community;

e. To develop character, students need opportunities for moral action;

f. Effective character education includes a meaningful and challenging academic curriculum that respects all learners and helps them succeed;

g. Character education should strive to develop students' intrinsic motivation;

h. The school staff must become a learning and moral community in which all share responsibility for character education and attempt to adhere to the same core values that guide the education of students;

i. Character education requires moral leadership from both staff and students;

j. The school must recruit parents and community members as full partners in the character-building effort;

Evaluation ofcharacter education should assess the character of the school, the school staff's functioning ascharacter educators, and the extent to which students manifest good characte. ${ }^{19}$

3. Character Education in Scheduling and Adding Lesson Hours

According to Lickona, there are six elements that must be met by a school to be able to cultivate morals in it, namely:

a. Leadership from the principal

b. Policies to enforce discipline

c. Build a sense of family at school

d. Democratic class management

e. Creating close cooperation between adults

f. Set aside time to deal with moral problems that arise in the school life environment, both small and large. ${ }^{20}$

\section{RESEARCH METHOD}

This research is descriptive qualitative research with a phenomenological approach. The data sources are primary and secondary data. Primary data were taken from the stakeholders of MAN 1 Mamuju through interviews. Meanwhile, secondary data were taken from documents and literature related to this research. The main instrument is the researcher himself as the key instrument, while the interview guide, observation and documents are complementary instruments. The analysis used is data reduction, data presentation and conclusion drawing.

${ }^{19}$ Lickona, Educating for Character, (New York: Bantam Books, 1991), p. 325.

${ }^{20}$ Lickona, Educating for Character,p. 325. 


\section{RESEARCH RESULTS AND DISCUSSION}

(Study at Madrasah Aliyah Negeri 1 Mamuju)

\section{A. Supporting and Inhibiting Factors of Character Education in Madrasah Aliyah Negeri 1 Mamuju}

The Nine Noble Habits have been described as habits to create an atmosphere of life with character in the previous section. The habituation includes the habit of starting the learning activities with praying together, congregational Zuhur prayer, 5S culture (Salam, Sapa, Senyum, Sopan and Santun), habituation of flag ceremony discipline, Duha prayer, Arabic and English language culture, as well as Friday literacy and clean culture/gymnastics. In this section, the researcher will describe the phenomena that are the supporting and inhibiting factors in the implementation of The Nine Nobel Habits for character education of students at MAN 1 Mamuju, West Sulawesi.

Like the other strategic efforts, Character Education of students through The Nine Nobel Habits at MAN 1 Mamaju also has several inhibiting and supporting factors.

\section{Inhibiting Factors}

The nine priority characters in MAN 1 Mamuju are the implementation of the Vision and Mission of MAN 1 Mamuju, which are summarized in the results of committee meetings, principals and all teachers because, in the K13 curriculum, the characters of students are the principals' things that would like to be strengthened. Implementing the nine characters that characterize MAN 1 Mamuju has been running for three years, with various inhibiting and supporting factors. According to the Deputy Head of Madrasa, Nurwahyudi, in the interview stated that:

"The inhibited implementation of the Nine Aspects in character building is the existence of stubborn students, sometimes arriving late, so they are usually not carried out effectively, especially literacy activities, congregational prayers, not following directions. These usually affect the delay in the process not running optimally ${ }^{21}$

In implementing the nine characters in MAN 1 Mamuju closely related to the religious field, certainty the target to be achieved is the religious spirit, such as students love Al-Qur'an, and they love their religion. As well as praying, it will grow the religious spirit of students. In terms of inculcating the character of students related to the religious atmosphere, there are several inhibiting factors, such as the following:

a. If the teacher is late to school for teaching, then the tadarrus learning process is not carried out;

b. During the holy month of Ramdhan, there is a reduction in learning hours therefore that the application of Tadarrus is not too emphasized and its application depends on the teacher who will teach in the class;

c. There are students who are sick and faint therefore they stop for a moment the tadarrus activity;

\footnotetext{
${ }^{21}$ Nur Wahyudin, Vice Principal of curriculum, interviewed, Mamuju, 09 August 2019.
} 
d. There are students who do not bring the Qur'an, sometimes it is difficult even though they are told to memorize sometimes there are students who do not pay attention;

e. Singing the compulsory national anthem is only for specific subjects such as PKN subjects for time efficiency. Therefore it is not optimal every time the teaching and learning process is carried out;

f. Sometimes the most inhibiting dhuhur prayer in congregation is from the ablution place where the water usually runs out, because they are still using drilled wells, students are wasteful using water, sometimes there are friends who don't get any;

g. The mushallah of MAN 1 Mamuju is still narrow which has not accommodated all students to have a midday prayer in congregation therefore that some students have to go out to pray at the nearest mosque. ${ }^{22}$

The other forms of obstacles, in the application of Indonesian, Arabic and English language culture, as follows:

a. The obstacles are from books that are not available and are still lacking, so students usually use one book in turn;

b. There are still stubborn students who were told to bring books but did not bring it and don't pay attention to their teachers, as a result it is not effective for them;

c. The obstacle from the teacher is that sometimes students are late so not all students follow the literacy applied by the school;

d. Non-routine implementation is also considered as an obstacle, where only once a week, namely Arabic on Wednesdays, English is done once a week in the afternoon after school hours;

e. Arabic Camp activities are held once a year;

f. English Camp activities are held once a month. ${ }^{23}$

2. Supporting Factors

As an inhibiting factor, in the implementation of The Nine Nobel Habits there were several supporting factors that were observed and acknowledged by several teachers who were actively involved in character education at MAN 1 Mamuju. In this section, the researcher describes the factors supporting the implementation of character education at MAN 1 Mamuju. Supporting factors in literacy habituation, among others, as conveyed by Muliadi, an English teacher as follows:

"Related to the facilities and infrastructure, for example, books, libraries and schools have facilitated each year to arrange budget for the procurement of books in the library. There were also contributions from students who brought their books during literacy activities. However, before that, we checked whether the books were suitable for reading at the age of Madrasah students. '24

\footnotetext{
${ }^{22}$ Asrianti, Physics Teacher MAN Mamuju, interviewed, Mamuju, 23 Mei 2019

${ }^{23}$ Muliani, English Teacher, interviewed, Mamuju, 23 Mei 2019

${ }^{24}$ Muliani, English Teacher, interviewed, 23 Mei 2019
} 
(Study at Madrasah Aliyah Negeri 1 Mamuju)

In general, the supporting factors for the implementation of character education at MAN 1 Mamuju are as follow:

a. Availability of professional teachers

b. Supporting facilities for learning

c. Applying Arabic culture which is a special feature of Madrasah

d. Picking the students up every Monday and Tuesday for taking part in language habituation

e. The interest of students is quite high in carrying out or participating in activities

f. The school prepares Al-Qur'an for students before starting the learning process

g. There are students who have Al-Qur'an

h. Conducive class atmosphere

i. Enthusiastic students

j. The teacher is always active and always reminds the students

k. School provides maximum support

1. Good response of the student so that the habituation program can run well

$\mathrm{m}$. The response of subject teachers in in the first hour of starting the learning process was very positive

n. The homeroom teacher's response is very positive

o. There is a mobile library that provides books for students to read.

p. Voluntary attitude that is willing to bring reading books for successful literacy habituation..$^{25}$

The presented supporting factors as described above, researchers can see the positive impact on the character education efforts for MAN 1 Mamuju students that there are inhibiting factors in the implementation of character education in MAN 1 Mamuju but do not cause the cessation of habituation programs or positive cultures that are built. It is clearly illustrated that the strength of MAN 1 Mamuju in building the character of its students depends on the commitment of the Madrasah principal, teachers, homeroom teachers, staff and support from community leaders, as well as school committees.

\section{B. Accomplishment of Character Education of MAN 1 Mamuju}

Based on 4 (four) Character Education Foundations, 5 (five) Islamic Education Goals, 9 (nine) Universal Values of Character Education, 11 (eleven) Character Education Principles, and 18 (eighteen) Character Education Values, MAN 1 Mamuju successfully develop character education based on the Vision, Mission, Work Program sourced from the 4 (four pillars) Program Pillars which are the derivatives of the K13 command. The mentioned achievements are as follows:

\section{The Formation of Religious Character}

The formation of the character of religiosity and patriotism of the students of MAN 1 Mamuju, this attitude is a positive impact of the habituation program of

\footnotetext{
${ }^{25}$ Hasnuddin, Vice Principal of curriculum, interviewed, Mamuju, 22 June 2019.
} 
students to pray together led by one of the students, The teaching and learning process begins as a form of total surrender of a servant to Allah SWT and asks for ease in understanding, peace of mind in learning and the benefits of knowledge gained. The formation of the character of religiosity and patriotism of the students of MAN 1 Mamuju positively impacts the habituation program of students to pray together led by one of the students. At the exact time, teachers have a sense of responsibility towards programs that have been mutually agreed upon curriculum development according to the will of K13.

\section{The Formation of Patriotism Character}

The formation of the Patriotism Character of the students of MAN 1 Mamuju is the result of singing the national anthem "Indonesia Raya" and the national songs, which are sung repeatedly at the beginning and the end of the teaching and learning process. The flag ceremony is every Monday morning which affects the mentality of the educated participants.

\section{Teacher Role Model}

This example is an infinite value in the teaching and learning process as well as in the social life of the community. In order to form the character of students, the most effective method is the exemplary method, where teachers set an example and students will see and follow the good attitudes of their teachers. One of the programs of MAN 1 Mamuju which is quite effective in shaping the character of students is $5 \mathrm{~S}$ culture (Salam, Senyum, Sapa, Sopan and Santun). Technically, the 5S culture is applied in every morning at school which is about five to ten minutes before the teaching and learning begins. The application of the $5 \mathrm{~S}$ culture produces two characters at once, namely the exemplary character of the teachers and the akhlaqul karimah of the students.

\section{Analysis of Character Education Implementation Achievement Results at MAN 1 Mamuju}

Conceptually and operationally, the Character Education Implementation Achievement Results at MAN 1 Mamuju cannot be separated from the ability of the principal in planning and achieving the following steps:

1. Planning, identifying the types of activities in schools that can realize character education, developing character education materials for each type of activity in schools, developing implementation plans for each activity, and preparing supporting facilities for the implementation of character education programs. This can be read in the profile of MAN 1 Mamuju in the initial discussion of the results of this research, which includes the Vision, Mission, Program, to the Main Tasks and Functions (Tupoksi) of the Madrasah Head, Deputy Head of Madrasah, Administration, Class Teacher, Subject Teacher to Assessment student learning outcomes. It's really an accountable money management and needs to be emulated.

2. Implementation, namely the formation of an integrated character with learning in all subjects, school management, and educational activities. This includes The Nine Nobel Habits, namely: 
(Study at Madrasah Aliyah Negeri 1 Mamuju)

a. Start and end the PMB by praying together, tadarrus al-Qur'an, singing the song "Indonesia Raya" and national songs

b. 5S Culture (Salam, Senyum, Sapa, Sopan dan Santun)

c. Habituation of the congregational dhuhur prayer

d. Flag Ceremony every Monday morning

e. Habituation of Duha prayer

f. Arabic-Speaking Culture

g. English-Speaking Culture

h. Literacy Culture and Friday Sadaqah

i. Clean Culture/Gymnastics

3. Monitoring and evaluation, are the activities to monitor the process of the character education programs implementing, which focus on the suitability of the implementation process of character education programs based on predetermined stages.

Thus the analysis of the character education implementation achievement results at MAN 1 Mamuju, and this is the final part of the data presentation, analysis and discussion of the results of this study, hopefully it will be useful.

\section{CLOSING}

In the implementation of the character education program at Madrasah Aliyah Negeri 1 Mamuju, there are factors that supporting or inhibiting it. As described in the section on the analysis of the achievement result of character education at MAN 1 Mamuju, there are supporting factors which is strategic in nature, and supporting factors those are technical and operational. Strategic in nature supporting factors are planning, controlling, and evaluation of the Head of MAN 1 Mamuju which is supported by all stakeholders. Meanwhile, technical operational supporting factors are: 1) the availability of professional teachers, 2) supporting facilities in learning, 3) applying Arabic culture which is a special characteristic of Madrasah, 4) students' high interest in implementing or following activities, 5) the school prepares Al-Qur'an for students before starting the teaching and learning process 6) there are students who have Al-Qur' an, and others.

\section{REFERENCES}

Presiden Republik Indonesia, Penguatan Pendidikan Karakter, Peraturan Presiden Republik Indonesia No. 87 Tahun 2017, 6 September 2017.

Shihab, Quraish. Tafsir Al-Misbah, Pesan, Kesan, dan Keserasian Al-Qur'an vol.10. Jakarta: Lantera Hati, 2011.

Salahudin, Anas dan Irwanto Alkrienciehie. Pendidikan Karakter Pendidikan Berbasis Agama dan Budaya Bangsa. Bandung: Pustaka Setia, 2013. 
Suparno P. Harapan Untuk Kurikulum Baru. Kompas, 29 September 2012.

Rukiyati, et.al. Dalam Jurnal Penanaman Nilai Karakter Tanggung Jawab Dan Kerja Sama Terintegrasi Dalam Perkuliahan Ilmu Pendidikan.

Departemen Agama RI Direktorat Jenderal Pendidikan Islam. Undang-Undang Republik Indonesia Nomor 20 Tahun 2003 tentang Sisdiknas. Jakarta: Depag Press, 2007.

Arifin. Pendidikan Islam Suatu Tinjauan Teoritis dan Praktis Berdasarkan Pendekatan Interdisipliner. Jakarta: Bumi Aksara.

Sudrajat, Akhmad. Tentang Pendidikan Karakter. Posted on 20 August 2010),http:www.pendidikan karakter.ac.id

Khan, Yahya. Pendidikan Karakter Berbasis Potensi Diri. Yogyakarta: PustakaPublishing, 2010.

Dimenson, Sara. Ed, Character is Key: How to Unlock the Best in Our Children and in Our Self. Ontario: John Wiley and Sons Canada, 2009.

Thomas, Lickona. Education for Character: How Our School Can Teach Respect and Responsibility. New York: Bantam Books, 1991.

Muhadjir, Noeng. Ilmu Pendidikan dan Perubahan Sosial. Yogyakarta: Rake Sarasin, 2003.

Johansson, E, et.al. "Practices For Teaching Moral Values in the EarlyYears: A Call for A Pedagogy of Participation". Education, Citizenship And Social Justice, p. 109.

Asmani, Jamal Ma'mur. Pendidikan Karakter di Sekolah. Yogyakarta: DIVA Press, 2011.

Nucci, L. P., \& Narvaez D. HandbookOf Moral And Character Education. New York: Routledge, 2008.

Kessler, M.A. Managing Classroom Behavior and Discipline. U.S.A: Shell Education, 2001.

Zuchdi, Darmiyati. "Pendidikan Karakter Melalui Pengembangan Keterampilan Hidup dalam Kurikulum Persekolahan". Laporan Penelitian Hibah Pasca 2005-2006. Yogyakarta: Lembaga Penelitian UNY, 2006.

Zarkasyi, Abdullah Syukri. Pola Pendidikan Pesantren Dalam Pembentukan Karakter Bangsa. The paper has presented in the Seminar: Pendidikan Karakter Bangsa melalui Pola Pendidikan Pesantren. Balitbang, Kemendiknas, 10-12 Desember 2010, di Hotel Salak, Bogor.

Kementerian Pendidikan Nasional, Pengembangan Pendidikan Budaya dan Karakter Bangsa. Jakarta: Kementrian Pendidikan Nasional, 2010.

Hasnuddin. Wakil Kepala Madrasah Bidang Kurikulum, Wawancara, Mamuju, 22 June 2019.

Fathurrohman, P. et.al, Pengembangan Pendidikan Karakter. 